\title{
榮養失調症二於ケル自律神經系ノ態度
}

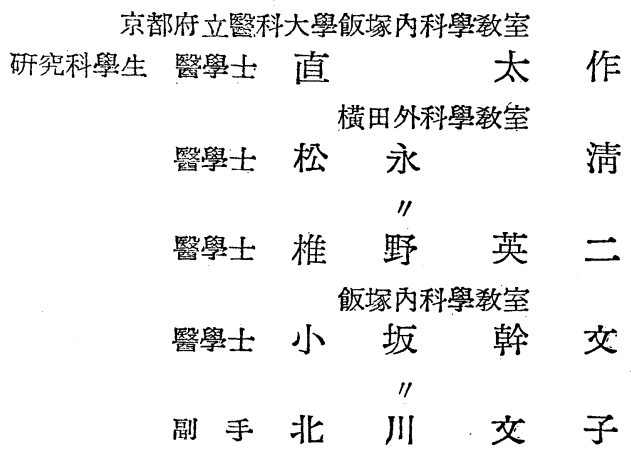

\section{Attitude of autonomic nervous system in Malnutrition (Epitome).}

\author{
By
}

\section{Tasaku Nao M.D., Mikibumi Kosaka M.D., Fumiko Kitagawa, lizuka Clinic of Kyoto Prefectural Medical College.}

Kiyoshi Matsunaga M.D., and Eiji Siino M.D.. Yokota Clinc of Kyoto Prefectural Medical College.

We performed pharmacodynamic Test of autonomic nervous system and then measuered motoric Chronaxia of an upper arm in 12 cases of malnutrition and found the results as follows;

1) Many negative results and tendency to tarrying and prolongation on pharmacodynamic Test may be partly due to impediment of local resorption, of course, this is the influence of diet causing Malnutrition.

2) The excessive variation of Chronaxia is not caused by oversensitivness of autonomic nervous system, but it shows the irritable delay of endorgan i.e. muscles.

3) Attitude of autonomic nervous system in Malnutrition does not mean the lack of strain but it meanes "labile".

（本論文）要旨八昭和 22 年 4 月第 20 回日本內分泌學會總會=於テ發表セり）

\section{緒言}

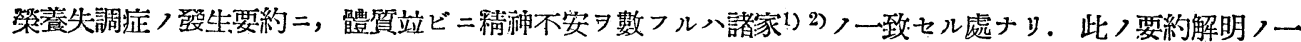

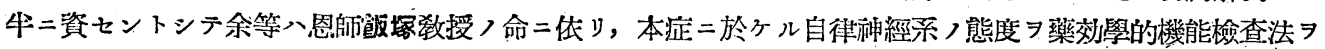
以テ究明，次ノ如キ成績 7 得タり。

\section{研究對照道ビ二㸴究方法}

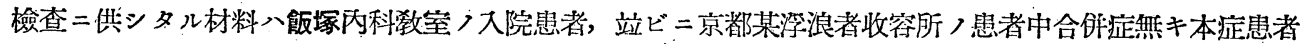

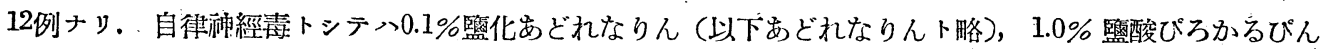

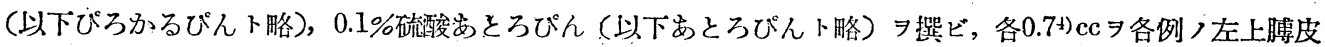

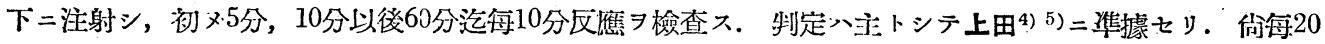
分二右上膊湤經，二頭膊筋，三頭膊筋〉くろなきしー6)(以下 Ch ト略)， ヨ英弘くろなきしめーたーニテ測 
定セリ.

$$
\text { 檢查成 績 }
$$

第1表 [1]ノ如ク，岕どれならん試驗中强反應

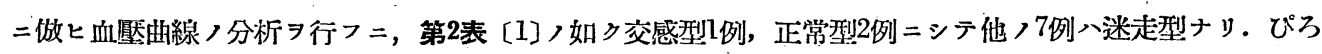
かるびん試驗中疑强反㷳1例 ニシテ他入凡テ弱鹰ヨ示セリ(第1表[2]). 然ルニあとろびん試驗八第1表[3]

第 1 表 (1)「あどれなりん」試驗

\begin{tabular}{|c|c|c|c|c|c|c|c|c|c|c|c|}
\hline \multicolumn{2}{|r|}{ 症，例 } & 1 & 2 & 3 & 4 & 5 & 6 & 7 & 8 & 9 & 10 \\
\hline \multirow{2}{*}{\multicolumn{2}{|c|}{$\begin{array}{l}\text { 血 壓上昇 } \\
\text { 脈 搏 頻 數 }\end{array}$}} & - & - & - & + & - & - & - & + & - & + \\
\hline & & - & - & + & - & - & - & - & + & + & - \\
\hline \multirow{3}{*}{ 副 } & 一心悸六進 & - & - & - & + & - & - & H & \pm & + & \pm \\
\hline & 般頝面督白 & - & - & - & + & \pm & - & + & - & - & - \\
\hline & 獎不 安 & - & - & - & - & - & - & + & - & - & - \\
\hline \multirow[t]{2}{*}{ 症 } & 反射䒕進 & - & - & - & - & - & + & + & - & + & - \\
\hline & 震 顫 & - & - & \pm & - & - & - & + & - & + & - \\
\hline \multirow[t]{2}{*}{ 狀 } & 體溫上昇 & - & - & - & - & - & - & - & - & - & - \\
\hline & 呼吸異常 & - & - & - & - & - & - & - & - & - & - \\
\hline
\end{tabular}

第 1 表（2）「びろかるびん」試驗

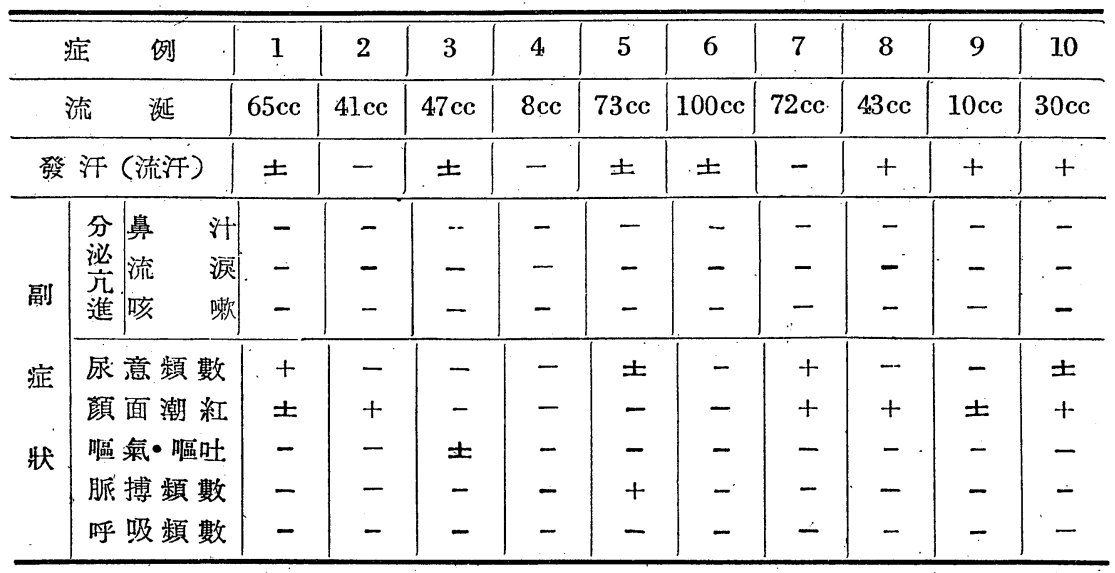

第 1 表（3）「あとろぴん」試驗

\begin{tabular}{|c|c|c|c|c|c|c|c|c|c|c|c|}
\hline & 宔，例 & 1 & 2 & 3 & 4 & 5 & 6 & 7 & 8 & 9 & 10 \\
\hline \multirow{2}{*}{$\begin{array}{l}\text { 脈 } \\
\text { 口 }\end{array}$} & 搏 頻 數 & - & + & - & + & - & + & + & - & + & - \\
\hline & 渴 & $H$ & + & + & + & \pm & + & + & - & + & - \\
\hline \multirow{6}{*}{ 副 } & 頭痛 & - & - & + & - & - & - & - & - & - & - \\
\hline & 心悸元進 & - & - & - & - & - & - & - & - & - & - \\
\hline & 瞳 孔散大 & - & - & + & - & - & - & + & - & - & - \\
\hline & 頋·面發赤 & - & - & + & + & - & - & - & - & - & - \\
\hline & 灼 熱 感 & - & - & \pm & \pm & - & - & - & - & - & - \\
\hline & 呼吸異常 & - & - & - & - & - & + & -- & - & - & - \\
\hline
\end{tabular}

第 25 卷 $7 \sim 9$ 
第 2 表
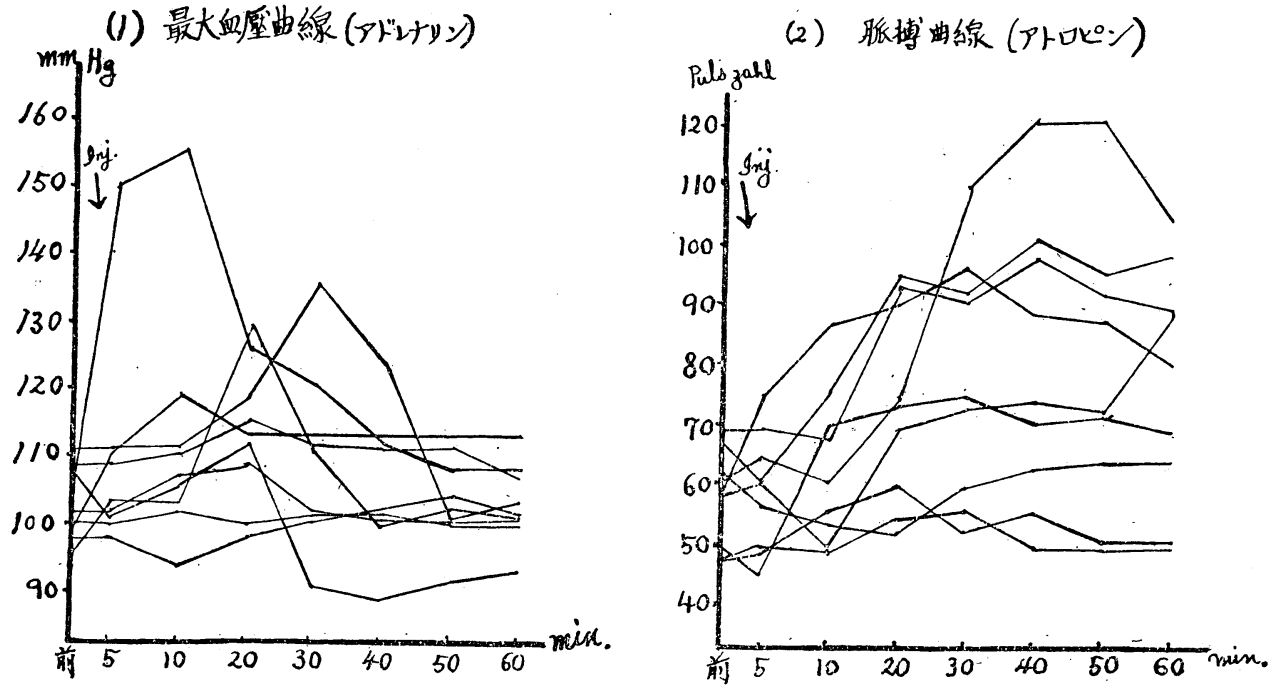

第 3 表

\begin{tabular}{|c|c|c|c|c|c|c|c|c|c|}
\hline & 症 & 例 & 性 & $\begin{array}{l}\text { 年 } \\
\text { 齡 }\end{array}$ & $\mid \begin{array}{c}\text { あどれなりん } \\
\text { 試 驗 }\end{array}$ & $\mid \begin{array}{c}\text { ひろかるひんん } \\
\text { 鿉 驗 }\end{array}$ & $\begin{array}{l}\text { あとろびん } \\
\text { 試 驗. }\end{array}$ & 制 & 定 \\
\hline 1 & 清 & 水 & $\hat{\sigma}$ & 46 & - & - & - & 正 & 常 \\
\hline 2 & 高 & 橋 & 우 & 59 & - & - & + & & \\
\hline 3 & 小 & 倉 & 우. & 23 & - & - & \pm & & \\
\hline 4 & 坂 & 口 & ๙ิ & 19 & - & - & + & & \\
\hline 5 & 柴 & 山 & $\hat{\delta}$ & 23 & - & - & - & 正 & 常 \\
\hline 6 & 須 & 崎 & $\hat{\delta}$ & 19 & - & \pm & + & & \\
\hline 7 & 田 & 光 & $\hat{\sigma}$ & 40 & - & - & + & \multirow{3}{*}{\multicolumn{2}{|c|}{ 交感神經圥進 }} \\
\hline & 西 & 尾 & $\hat{\delta}$ & 36 & + & - & - & & \\
\hline 9 & 七 & 里 & $\hat{\delta}$ & 37 & - & - & + & & \\
\hline 10 & 橋 & 本 & $\hat{\delta}$ & 51 & - & - & - & 正 & 常 \\
\hline
\end{tabular}

ノ如ク弱区應4例，疑强反應1例，他ノ5例八强反隹 殆ンド認メズ 且ツ第2表〔2〕フ胍搏曲線ニ明カナル如ク，心臟二對スルむとろびんノ促進的現象著明ナル

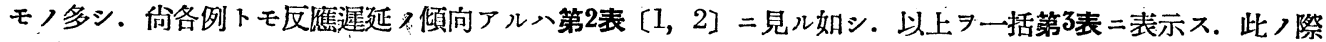

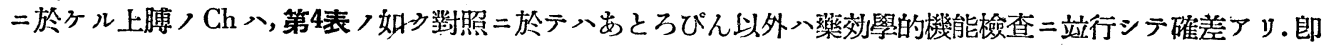
チむどれなりん八弱反應ノ例二，びろかるびん八强反應ノ例二，くろなきしー Ch 増大著シ，本症患者二於

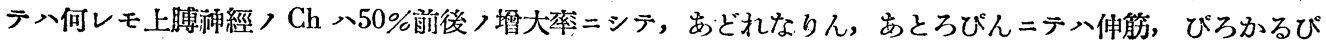

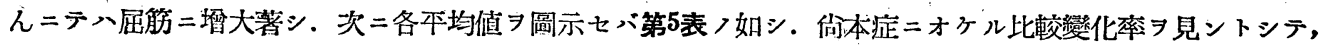
本症例ノ各本均變化率絕對值卜對照例ノソレトノ陶习探ルニ，第6表二示セル如ク屈筋ハぁどれなりん，ぴ ろかるびんニ，伸箦ハあとろびん二變化率大ナリ.

\section{總括並比考按}

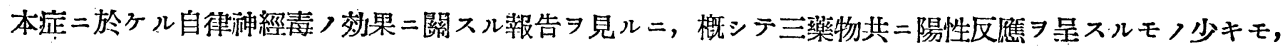

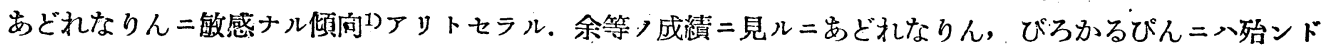

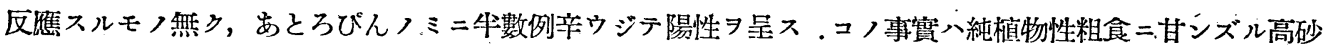

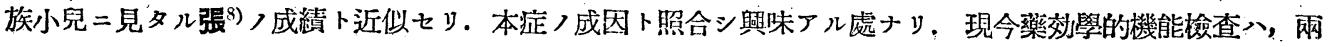


第 4 表 榮養失調症ニ於ケル自律神經㱟ノ上膊「くろなきし一」二及ボス影響

I. (あどれなりん)

對照

\begin{tabular}{|c|c|c|c|c|c|c|c|c|c|c|c|c|c|c|}
\hline \multirow{2}{*}{ 症 } & \multirow{2}{*}{ 例 } & \multirow{2}{*}{$\begin{array}{l}\text { 檢 } \\
\frac{\text { 宣 }}{\text { 等 }}\end{array}$} & & \multicolumn{2}{|c|}{ 注 射 前 } & \multicolumn{2}{|c|}{ 注射後 $20^{\prime}$} & \multicolumn{2}{|c|}{ " $40^{\prime}$} & \multicolumn{2}{|c|}{ " $60^{\prime}$} & \multicolumn{3}{|c|}{ 變化率\% } \\
\hline & & & & $\mathrm{Rh}^{\mathrm{v}}$ & $\mathrm{Ch}^{\sigma}$ & $\mathrm{Rh} v$ & $\mathrm{Cb}^{\sigma}$ & $\mathrm{Rh}^{\mathrm{v}}$ & $\mathrm{Ch}^{\sigma}$ & $\mathrm{Rh}^{\mathrm{v}}$ & $\mathrm{Ch}^{\sigma}$ & Rh. & Ch. & 應 \\
\hline & & \multirow{3}{*}{$\begin{array}{l}6 / \text { III } \\
1947\end{array}$} & 上 & 45 & 0.36 & 34 & 0.32 & 41 & 0.28 & 50 & 0.32 & & & \\
\hline & & & $=$ & 37 & 0.24 & 21 & 0.24 & 17 & 0.20 & 35 & 0.20 & & & + \\
\hline & & & $\equiv$ & 54 & 0.36 & 66 & 0.36 & 55 & 0.80 & 57 & 0.82 & & & \\
\hline \multirow{3}{*}{$2{ }^{\text {河 }}$} & \multirow{3}{*}{$\begin{array}{r}\text { 村 } \\
\text { 19歲 }\end{array}$} & \multirow{3}{*}{$\begin{array}{c}6 / \text { II } \\
" 1\end{array}$} & 上 & 39 & 0.28 & 58 & 0.32 & 90 & 0.72 & 60 & 0.40 & & & \\
\hline & & & $=$ & 34 & 0.36 & 69 & 0.28 & 66 & 0.24 & 50 & 0.28 & & & + \\
\hline & & & $\equiv$ & 105 & 0.40 & 117 & 0.44 & 120 & 0.36 & 150 & 0.40 & & & \\
\hline \multirow{3}{*}{ 平 } & \multirow{3}{*}{\multicolumn{2}{|c|}{ 均 }} & 上 & 42 & 0.32 & 46 & 0.32 & 66 & 0.50 & 55 & 0.36 & +50 & +56 & \\
\hline & & & $=$ & 36 & 0.30 & 45 & 0.26 & 44 & 0.22 & 43 & 0.24 & +25 & -26 & \\
\hline & & & $\Xi$ & 80 & 0.38 & 92 & 0.40 & 88 & 0.58 & 104 & 0.61 & +30 & +60 & \\
\hline & \multirow{3}{*}{$\begin{array}{r}\text { 野 } \\
29 \text { 歲 }\end{array}$} & \multirow{3}{*}{$\begin{array}{l}6 / \text { III } \\
1947\end{array}$} & 上 & 53 & 0.08 & 52 & 0.24 & 60 & 0.56 & 58 & 0.16 & & & \\
\hline & & & $=$ & 56 & 0.16 & 43 & 0.16 & 50 & 1.06 & 56 & 0.16 & & & $T$ \\
\hline & & & $\doteq$ & 56 & 0.28 & 88 & 0.40 & 103 & 0.40 & 60 & 0.56 & & & \\
\hline \multirow{3}{*}{ 4. $\begin{array}{c}\text { 小 } \\
\text { 令 }\end{array}$} & \multirow{3}{*}{$\begin{array}{r}\text { 坂 } \\
27 \text { 歲 }\end{array}$} & \multirow{3}{*}{ /1 } & 上 & 66 & 0.32 & 64 & 0.24 & 60 & 0.28 & 52 & 0.24 & & & \\
\hline & & & 二 & 22 & 0.12 & 31 & 0.08 & 30 & 0.08 & 16 & 0.12 & & & - \\
\hline & & & $\equiv$ & 36 & 0.12 & 44 & 0.08 & 50 & 0.16 & 40 & 0.12 & & & \\
\hline \multirow{3}{*}{ 5. 㨁 } & & \multirow{3}{*}{$\begin{array}{l}/ \text { III } \\
\text { " }\end{array}$} & 上 & 40 & 0.12 & 51 & 0.84 & 39 & 0.96 & 45 & 0.28 & & & \\
\hline & & & $=$ & 45 & 0.08 & 49 & 0.12 & 41 & 0.16 & 43 & 0.12 & & & - \\
\hline & & & $\equiv$ & 50 & 0.16 & 50 & 0.84 & 72 & 0.44 & 54 & 0.28 & & & \\
\hline \multirow{3}{*}{ 平 } & \multirow{3}{*}{\multicolumn{2}{|c|}{ 均 }} & 上 & 54 & 0.17 & 56 & 0.44 & 53 & 0.60 & 52 & 0.23 & $\pm \mathbf{3}$ & +252 & \\
\hline & & & 二 & 41 & 0.12 & 41 & 0.12 & 41 & 0.13 & 38 & 0.13 & -7 & +8 & \\
\hline & & & $\equiv$ & 53 & 0.19 & 61 & 0.44 & 75 & 0.33 & 51 & 0.32 & $\begin{array}{l}+41 \\
-3 \\
\end{array}$ & +131 & \\
\hline \multirow{3}{*}{ 總 } & \multirow{3}{*}{ 平 } & & 上 & 49 & 0.23 & 22 & 0.39 & 58 & 0.56 & 53 & 0.28 & $\begin{array}{l}+17 \\
-55\end{array}$ & $+1,43$ & \\
\hline & & 均 & $=$ & 39 & 0.19 & 41 & 0.18 & 41 & 0.17 & 40 & 0.18 & +5 & -5 & \\
\hline & & & $\equiv$ & 69 & 0.25 & 73 & 0.42 & 80 & 0.43 & 72 & 0.44 & +15 & +76 & \\
\hline
\end{tabular}

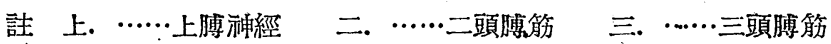

整養失調症

\begin{tabular}{|c|c|c|c|c|c|c|c|c|c|c|c|c|c|c|}
\hline \multirow{2}{*}{ 症 } & \multirow{2}{*}{ 例 } & \multirow{2}{*}{$\begin{array}{l}\text { 檢 } \\
\text { 䭪 } \\
\text { 日 }\end{array}$} & & \multicolumn{2}{|c|}{ 注 射 前 } & \multicolumn{2}{|c|}{ 注射後 20' } & \multicolumn{2}{|c|}{ ') $40^{\prime}$} & \multicolumn{2}{|c|}{ " $60^{\prime}$} & \multicolumn{2}{|c|}{ 變化率\% } & \multirow{2}{*}{ 友 } \\
\hline & & & & $\mathrm{Rh}^{\mathrm{v}}$ & $\mathrm{Ch}^{\sigma}$ & $\mathrm{Rh}^{\mathrm{v}}$ & $\mathrm{Ch}^{\sigma}$ & $\mathrm{Rh}^{\mathrm{v}}$ & $\mathrm{Ch}^{\sigma}$ & $\operatorname{Rh}^{v}$ & $\mathrm{Ch}^{\sigma}$ & Rh. & Ch. & \\
\hline \multirow{3}{*}{1.} & 属 & $27 \pi$ & 上 & 43 & 0.28 & 59 & 0.24 & 54 & 0.28 & 49 & 0.40 & +37 & +43 & \\
\hline & & & $=$ & 42 & 0.32 & 45 & 0.08 & 40 & 0.20 & 54 & 0.28 & +28 & -75 & + \\
\hline & 35歲 & 1947 & $\equiv$ & 52 & 0.40 & 69 & 0.16 & 40 & 0.56 & 57 & 0.44 & $\begin{array}{l}+32 \\
-23\end{array}$ & +40 & \\
\hline \multirow{3}{*}{2} & & $27 \pi \mathbb{I}$ & 上 & 59 & 0.12 & 57 & 0.12 & 66 & 0.24 & 81 & 0.24 & & & \\
\hline & & & $=$ & 50 & 0.20 & 62 & 0.12 & 67 & 0.16 & 56 & 0.12 & & & - \\
\hline & 37歲 & "I & $\equiv$ & 67 & 0.52 & 51 & 4.00 & 68 & 0.72 & 81 & 0.40 & & & \\
\hline
\end{tabular}




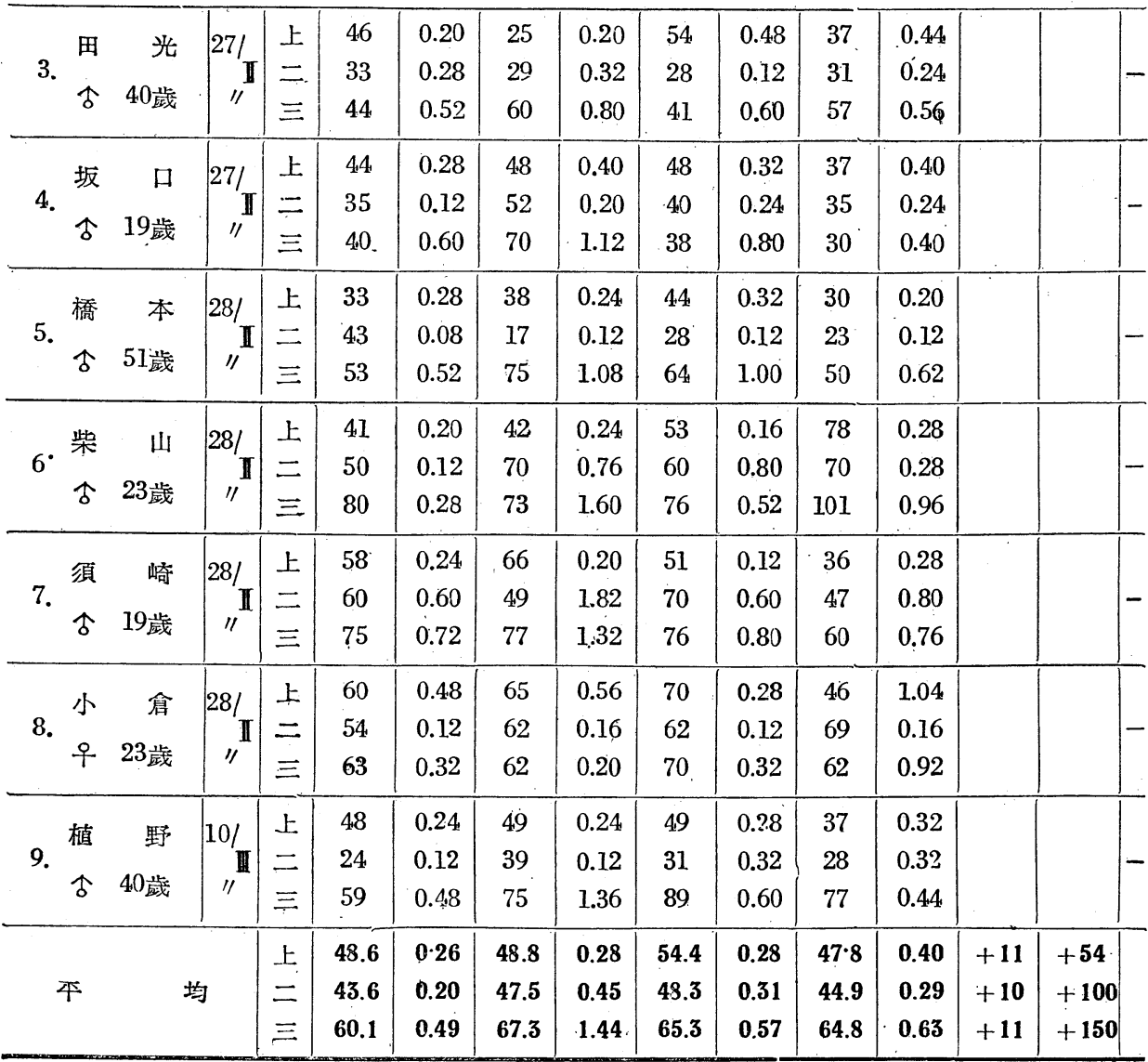

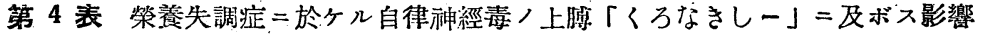
II (びろかるびん)

對 䀡

\begin{tabular}{|c|c|c|c|c|c|c|c|c|c|c|c|c|c|c|c|}
\hline \multirow{2}{*}{ 泟 } & \multirow{2}{*}{\multicolumn{2}{|c|}{ 例 }} & \multirow{2}{*}{$\begin{array}{l}\text { 檢 } \\
\text { 查 } \\
\text { 白 }\end{array}$} & & \multicolumn{2}{|c|}{ 注 射 前 } & \multicolumn{2}{|c|}{ 注射後 $20^{\prime}$} & \multicolumn{2}{|c|}{ " $40^{\prime}$} & \multicolumn{2}{|c|}{ i) $60^{\prime}$} & \multicolumn{2}{|c|}{ 變化率\% } & \multirow{2}{*}{ 反 } \\
\hline & & & & & $\mathrm{Rh}^{\mathrm{v}}$ & $\mathrm{Ch} \sigma$ & $\mathrm{Rh}^{\mathrm{v}}$ & $\mathrm{Ch}^{\sigma}$ & $\mathrm{Rh}^{\mathrm{v}}$ & $\mathrm{Ch}^{\sigma}$ & $\mathrm{Rh}^{\mathrm{v}}$ & $\mathrm{Ch}^{\sigma}$ & Rh. & Ch. & \\
\hline \multirow{3}{*}{1.} & & & \multirow{2}{*}{$8 /$ 埴 } & 上 & 31 & 0.18 & 20 & 0.26 & 21 & 0.40 & 25 & 0.12 & & & \multirow{3}{*}{+} \\
\hline & & & & $=$ & 27 & 0.08 & 25 & 0.08 & 30 & 0.12 & 15 & 0.12 & & & \\
\hline & $\delta$ & 29歲 & 1947 & $\equiv$ & 50 & 0.36 & 41 & 0.64 & 41 & 0.28 & 40 & 0.32 & & & \\
\hline \multirow{3}{*}{2.} & & & $8 /$ III & 上 & 79 & 0.10 & 48 & 0.14 & 42 & 0.30 & 47 & 0.26 & & & \multirow{3}{*}{+} \\
\hline & & & & $=$ & 18 & 0.08 & 19 & 0.08 & 29 & 0.08 & 17 & 0.12 & & & \\
\hline & & & "I & $\equiv$ & 43 & 0.12 & .24 & 0.12 & 27 & 0.40 & 24 & 0.20 & & & \\
\hline \multirow{3}{*}{\multicolumn{2}{|c|}{ 平 }} & \multirow{3}{*}{\multicolumn{2}{|c|}{ 均 }} & 上 & 55 & 0.14 & 34 & 0.20 & 32 & 0.35 & 36 & 0.19 & -41 & +150 & \\
\hline & & & & $=$ & 23 & 0.08 & 22 & 0.08 & 30 & 0.10 & 16 & 0.12 & \pm 30 & +50 & \\
\hline & & & & $\equiv$ & 47 & 0.24 & 33 & 0.38 & 34 & 0.34 & 32 & 0.26 & -31 & +58 & \\
\hline \multirow{3}{*}{3.} & & & \multirow{3}{*}{$\begin{array}{l}8 / \text { 且 } \\
1947\end{array}$} & 上 & 34 & 0.16 & 44 & 0.14 & 39 & 0.20 & 40 & 0.12 & & & \\
\hline & & & & $=$ & 58 & 0.12 & 52 & 0.16 & 48 & 0.16 & .50 & 0.08 & & & - \\
\hline & & & & $\equiv$ & 60 & 0.36 & 47 & 0.36 & 50 & 0.24 & 66 & 0.20 & & & \\
\hline
\end{tabular}




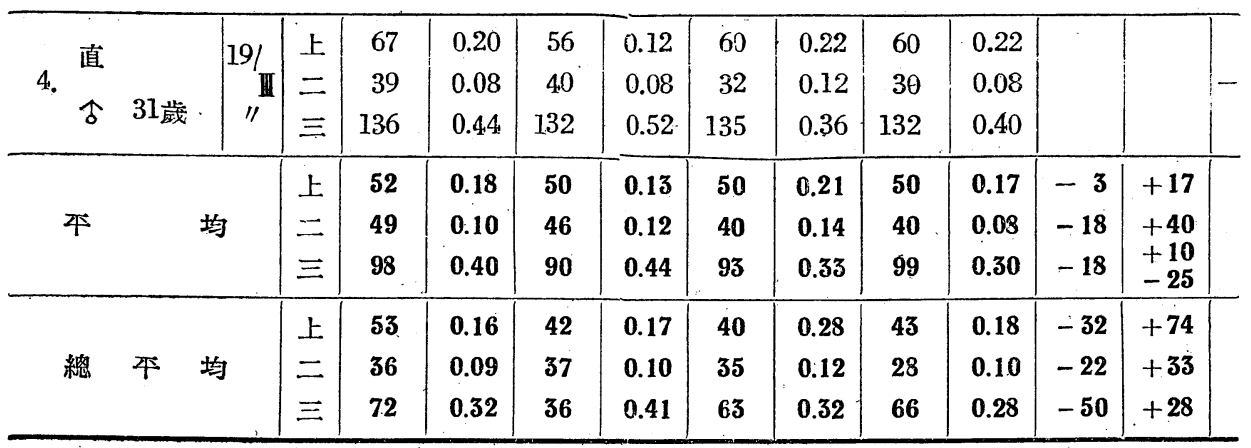

註. 上.…上膊神經 三.……頭膊筋 三. …..頭膊筋

榮養失 調 症

\begin{tabular}{|c|c|c|c|c|c|c|c|c|c|c|c|c|c|c|}
\hline \multirow{2}{*}{ 症 } & \multirow{2}{*}{ 例 } & \multirow{2}{*}{$\begin{array}{l}\text { 檢 } \\
\text { 查 } \\
\text { 日 }\end{array}$} & & \multicolumn{2}{|c|}{ 注 射 前 } & \multicolumn{2}{|c|}{ 注射後 $20^{\prime}$} & \multicolumn{2}{|c|}{ " $40^{\prime}$} & \multicolumn{2}{|c|}{ " $60^{\prime}$} & \multicolumn{2}{|c|}{ 變化率\% } & \multirow{2}{*}{ 反 } \\
\hline & & & & $\mathrm{Rh}^{\mathrm{v}}$ & $\mathrm{Ch}^{\sigma}$ & $R h^{v}$ & $\operatorname{Ch} \sigma$ & $\mathrm{Rh}^{\mathrm{v}}$ & $\mathrm{Ch} \sigma$ & $\mathrm{Rh}^{\mathrm{v}}$ & $\mathrm{Ch}_{\mathrm{h}} \sigma$ & $\mathrm{Rh}$ & $\mathrm{Ch}$ & \\
\hline \multirow{3}{*}{1.} & \multirow{3}{*}{$\begin{array}{l}\text { 崎 } \\
\text { 19歲 }\end{array}$} & \multirow{3}{*}{$\begin{array}{l}2 / \mathbb{I I} \\
1947\end{array}$} & 上 & .40 & 0.20 & 43 & 0.24 & 42 & 0.28 & 46 & 0.16 & +15 & +44 & \\
\hline & & & 二 & 41 & 0.12 & 40 & 0.24 & 49 & 0.46 & 50 & 0.40 & +21 & +283 & \pm \\
\hline & & & $\doteq$ & 74 & 0.68 & 53 & 1.92 & 57 & 1.28 & 73 & 0.36 & -14 & +182 & \\
\hline \multirow{3}{*}{ 2. 坂 } & \multirow{3}{*}{$\begin{array}{r}\text { 口 } \\
\text { 19歲 }\end{array}$} & \multirow{3}{*}{$\begin{array}{c}1 / \text { III } \\
11\end{array}$} & 上 & 45 & 0.24 & 28 & 0.20 & 34 & 0.16 & 23 & 0.40 & & & \\
\hline & & & 二 & 39 & 0.56 & 42 & 0.64 & 35 & 0.80 & 34 & 0.48 & & & - \\
\hline & & & $\equiv$ & 40 & 0.96 & 20 & 0.68 & 46 & 0.83 & 30 & 0.92 & & & \\
\hline \multirow{3}{*}{3.} & \multirow{3}{*}{$\begin{array}{r}\text { 山 } \\
23 \text { 歲 }\end{array}$} & \multirow{3}{*}{$\begin{array}{c}2 / \text { III } \\
\prime \prime\end{array}$} & 上 & 62 & 0.08 & 46 & 0.12 & 32 & 0.28 & 47 & 0.20 & & & \\
\hline & & & $=$ & 48 & 0.08 & 53 & 0.08 & 49 & 0.32 & 44 & 0.12 & & & - \\
\hline & & & $\equiv$ & 64 & 1.20 & 100 & 0.80 & 58 & 0.72 & .50 & 1.04 & & & \\
\hline & \multirow{3}{*}{$\begin{array}{r}\text { 尾 } \\
35 \text { 歲 }\end{array}$} & \multirow{3}{*}{$\begin{array}{c}1 / \text { II } \\
\prime \prime\end{array}$} & 上 & 48 & 0.20 & 37 & 0.32 & 47 & 0.24 & 41 & 0.34 & & & \\
\hline & & & $=$ & 35 & 0.20 & 11 & 0,24 & 26 & 0.40 & 17 & 0.20 & & & - \\
\hline & & & $\equiv$ & 70 & 0.56 & 33 & 0.20 & 45 & 0.36 & 34 & 0.36 & & & \\
\hline \multirow{3}{*}{5.} & \multirow{3}{*}{$\begin{array}{r}\text { 本 } \\
51 \text { 歲 }\end{array}$} & \multirow{3}{*}{$\begin{array}{c}1 / \text { III } \\
\prime \prime\end{array}$} & 上 & 22 & 1.00 & 36 & 1.28 & 21 & 0.80 & 26 & 0.96 & & & \\
\hline & & & $=$ & 30 & 0.20 & 20 & 0.08 & 34 & 0.36 & 22 & 0.32 & & & - \\
\hline & & & $\equiv$ & 55 & 0.84 & 47 & 1.76 & 60 & 2.40 & 70 & 0.56 & & & \\
\hline \multirow{3}{*}{6.} & \multirow{3}{*}{$\begin{array}{r}\text { 里 } \\
\text { 37歲 }\end{array}$} & \multirow{3}{*}{$\begin{array}{c}2 / \text { II } \\
\text { II }\end{array}$} & 上 & 56 & 0.20 & 54 & 0.24 & 40 & 0.20 & 42 & 0.20 & & & \\
\hline & & & $=$ & 41 & 0.08 & 60 & 0.32 & 40 & 0.20 & 46 & 0.28 & & & - \\
\hline & & & $\equiv$ & 68 & 0.16 & 73 & 0.64 & 69 & 0.66 & 76 & 0.80 & & & \\
\hline & 光 & $1 / \mathbb{I}$ & 上 & 4.7 & 0.20 & 34 & 0.28 & 29 & 0.24 & 37 & 0.32 & & & \\
\hline 7. & & & $=$ & 23 & 0.04 & 30 & 0.08 & 20 & 0.28 & 25 & 0.40 & & & - \\
\hline & 40 歲 & 11 & $\equiv$ & 40 & 0.24 & 37 & 0.23 & 50 & 0.36 & 38. & 0.16 & & & \\
\hline & & $10 /$ & 上 & 49 & 0.44 & 43 & 0.20 & 64 & 0.40 & 50 & 0.40 & & & \\
\hline 8. & & III & 二 & 40 & 0.36 & 40 & 0.32 & 42 & 1.08 & 60. & 1.08 & & & - \\
\hline & 23歲 & 11 & $\equiv$ & 68 & 0.40 & 47 & 1.04 & 55 & 0.58 & 46 & 0.92 & & & \\
\hline & & 121 & 上 & 71 & 0.32 & 46 & 0.36 & 36 & 0.16 & 60 & 0.36 & & & \\
\hline 9. & & III & $=$ & 30 & 0.32 & 32 & 0.28 & 24 & 0.16 & 25 & 0.24 & & & - \\
\hline & 40 盛 & 11 & $\equiv$ & 54 & 0.68 & 56 & 0.76 & 70 & 0.76 & 50 & 0.64 & & & \\
\hline
\end{tabular}




\begin{tabular}{ll|l|l|l|l|l|l|l|l|l|l|r|}
\hline \multirow{3}{*}{ 平 } & 上 & 50 & 0.21 & 41 & 0.23 & 39 & 0.31 & 40 & 0.34 & -22 & +62 \\
& $=$ & 34 & 0.22 & 35 & 0.29 & 33 & 0.45 & 33 & 0.39 & \pm 3 & +104 \\
& & $\equiv$ & 55 & 0.63 & 53 & 0.76 & 57 & 0.83 & 49 & 0.65 & +4 & +31 \\
\hline
\end{tabular}

第 4 表 榮養失調症ニ於ヶル的律祍經毒ノ上膊「くろなきし一」こ及ボス影響 而 (あとろびん)

對 照

\begin{tabular}{|c|c|c|c|c|c|c|c|c|c|c|c|c|c|c|}
\hline \multirow{2}{*}{ 症 } & \multirow{2}{*}{ 例 } & \multirow{2}{*}{$\begin{array}{l}\text { 檢 } \\
\text { 查 } \\
\text { 日 }\end{array}$} & & \multicolumn{2}{|c|}{ 注 射 前 } & \multicolumn{2}{|c|}{ 注射後 $20^{\prime}$} & \multicolumn{2}{|c|}{ " $40^{\prime}$} & \multicolumn{2}{|c|}{ " $60^{\prime}$} & \multicolumn{2}{|c|}{ 變化䋅\% } & \multirow{2}{*}{$\mid \begin{array}{l}\text { 友 } \\
\text { 應 }\end{array}$} \\
\hline & & & & $\mathrm{Rh}^{\mathrm{v}}$ & $\mathrm{Ch}^{\sigma}$ & $\mathrm{Rh}^{\mathrm{A}}$ & $\mathrm{Ch}^{\sigma}$ & $\mathrm{Rh}^{\mathrm{v}}$ & $\mathrm{Ch}^{\sigma}$ & $\mathrm{Rh}^{\mathbf{v}}$ & $\mathrm{Ch} \sigma$ & Rh. & Ch. & \\
\hline \multirow{3}{*}{ 1. 㐫 } & \multirow{3}{*}{$\begin{array}{r}\text { 山 } \\
\text { 36歲 }\end{array}$} & \multirow{3}{*}{$\begin{array}{l}18 / \\
\text { III } \\
1947\end{array}$} & 上 & 60 & & 64 & 0.36 & 51 & 0.24 & 48 & 0.32 & -20 & -25 & \\
\hline & & & $=$ & 37 & 0.08 & 28 & 0.08 & 36 & 0.12 & 50 & 0.12 & +33 & +50 & + \\
\hline & & & $\equiv$ & 60 & 0.28 & 72 & 0.24 & 75 & 0.28 & 60 & 0.32 & +25 & +14 & \\
\hline \multirow{3}{*}{2.} & \multirow{3}{*}{$\begin{array}{r}\text { 野 } \\
\text { 29歲 }\end{array}$} & \multirow{3}{*}{$\begin{array}{c}7 / \text { 田 } \\
11\end{array}$} & 上 & 72 & 0.40 & 62 & 0.36 & 54 & 0.32 & .56 & 0.12 & & & \\
\hline & & & $=$ & 54 & 0.12 & 55 & 0.12 & 50 & 0.20 & 67 & 0.24 & & & - \\
\hline & & & 三 & 90 & 0.32 & 90 & 0.28 & 75 & 0.32 & 93 & 0.32 & & & \\
\hline \multirow{3}{*}{ 3. 河 } & \multirow{3}{*}{$\begin{array}{r}\text { 村 } \\
19 \text { 歲 }\end{array}$} & \multirow{3}{*}{$\begin{array}{c}7 / 11 \\
11\end{array}$} & 上 & 50 & 0.32 & 47 & 0.36 & 40 & 0.36 & 40 & 0.32 & & & \\
\hline & & & $=$ & 24 & 0.24 & 30 & 0.32 & 40 & 0.40 & 30 & 0.20 & & & - \\
\hline & & & $\equiv$ & 100 & 0.28 & 100 & 0.36 & 104 & 0.28 & 107 & 0.24 & & & \\
\hline & \multirow{3}{*}{$\begin{array}{r}\text { 村 } \\
26 \text { 歲 }\end{array}$} & \multirow{3}{*}{$\begin{array}{c}7 / \mathbb{I} \\
11\end{array}$} & 上 & 50 & 0.16 & 52 & 0.32 & 50 & 0.28 & 49 & 0.24 & & & \\
\hline & & & $=$ & 30 & 0.24 & 39 & 0.20 & 33 & 0,28 & 43 & 0.20 & & & - \\
\hline & & & $\equiv$ & 80 & 0.28 & 81 & 0.32 & 76 & 0.32 & 79 & 0.28 & & & \\
\hline \multirow{3}{*}{ 平 } & \multirow{3}{*}{\multicolumn{2}{|c|}{ 均 }} & 上 & 57 & 0.29 & 54 & 0.35 & 48 & 0.31 & 48 & 0.23 & -18 & $\begin{array}{l}+20 \\
-20\end{array}$ & \\
\hline & & & 二 & 36 & 0.20 & 41 & 0.21 & 41 & 0.29 & 47 & 0.21 & +30 & +45 & \\
\hline & & & $\equiv$ & 90 & 0.29 & 90 & 0.32 & 85 & 0.31 & 93 & 0.28 & $\begin{array}{r}-5 \\
+\quad 3 \\
\end{array}$ & +10 & \\
\hline \multirow{3}{*}{ 總 } & \multirow{3}{*}{ 平 } & \multirow{3}{*}{ 均 } & 上 & 58 & 0.30 & 56 & 0.35 & 50 & 0.30 & 48 & 0.25 & -20 & +17 & \\
\hline & & & $=$ & 36 & 0.17 & 38 & 0.18 & 40 & 0.25 & 48 & 0.20 & +33 & +40 & \\
\hline & & & $\equiv$ & 83 & 0.29 & 85 & $\mathbf{0 . 3 0}$ & 82 & 0.30 & 85 & 0.29 & +2 & \pm 3 & \\
\hline
\end{tabular}

註. 上. ……上膊神經

二. $\cdots \cdots$ 二頭膊筋 三. $\cdots \cdots$ 三頭膊筋

榮養失調症

\begin{tabular}{|c|c|c|c|c|c|c|c|c|c|c|c|c|c|c|}
\hline \multirow{2}{*}{ 症 } & \multirow{2}{*}{ 例 } & \multirow{2}{*}{$\begin{array}{l}\text { 檢 } \\
\text { 臬 } \\
\text { 日 }\end{array}$} & & \multicolumn{2}{|c|}{ 注 射 前 } & \multicolumn{2}{|c|}{ 注射後 $20^{\prime}$} & \multicolumn{2}{|c|}{$\Rightarrow \quad 40^{\prime}$} & \multicolumn{2}{|c|}{ " $60^{\prime}$} & \multicolumn{2}{|c|}{ 變化率 \% } & \multirow{2}{*}{ 质 } \\
\hline & & & & $\mathrm{Rh}^{\mathrm{v}}$ & $\mathrm{Ch}^{\sigma}$ & $\mathrm{Rh}^{\mathbf{v}}$ & $\mathrm{Ch}^{\sigma}$ & $\mathrm{Rh}^{\mathrm{v}}$ & $\mathrm{Ch} \sigma$ & $\mathrm{Rh}^{\mathrm{v}}$ & $\mathrm{Ch}^{\sigma}$ & Rh. & Ch. & \\
\hline \multirow{3}{*}{ 1. 田 } & \multirow{3}{*}{$\begin{array}{r}\text { 光 } \\
40 \text { 歲 }\end{array}$} & \multirow{3}{*}{$\begin{array}{c}4 / \text { III } \\
1947\end{array} \mid$} & 上 & 27 & 0.24 & 36 & 0.40 & 50 & 0.56 & 36 & 0.24 & & & \multirow{3}{*}{+} \\
\hline & & & $=$ & 39 & 0.72 & 30 & 0.16 & 30 & 0.16 & 70 & 0.80 & & & \\
\hline & & & $\equiv$ & 55 & 0.40 & 79 & 2.40 & 70 & 0.40 & 53 & 0.44 & & & \\
\hline \multirow{3}{*}{2.} & \multirow{3}{*}{$\begin{array}{r}\text { 口 } \\
\text { 19歲 }\end{array}$} & \multirow{3}{*}{$\begin{array}{c}4 / \text { II } \\
11\end{array}$} & 上 & 30 & $0: 24$ & 55 & 0.52 & 43 & 0.20 & 40 & 0.12 & & & \multirow{3}{*}{+} \\
\hline & & & $=$ & 40 & 0.24 & 50 & 0.50 & 56 & 0.24 & 40 & 0.20 & & & \\
\hline & & & $\equiv$ & 45 & 0.20 & 50 & 0.20 & 43 & 0.24 & 43 & 0.16 & & & \\
\hline \multirow{3}{*}{3.} & \multirow{3}{*}{$\begin{array}{r}\text { 里 } \\
\text { 37歲 }\end{array}$} & \multirow{3}{*}{$\mid \begin{array}{c}5 / \text { 目 } \\
11\end{array}$} & 上 & 33 & 0.24 & 44 & 0.12 & 52 & 0.28 & 47 & 0.24 & & & \multirow{3}{*}{+} \\
\hline & & & 二 & 90 & 0.12 & 67 & 0.20 & 64 & 0.16 & 50 & 0.40 & & & \\
\hline & & & 三 & 73 & 0.20 & 70 & 0.12 & 79 & 0.32 & 73 & 0.38 & & & \\
\hline
\end{tabular}




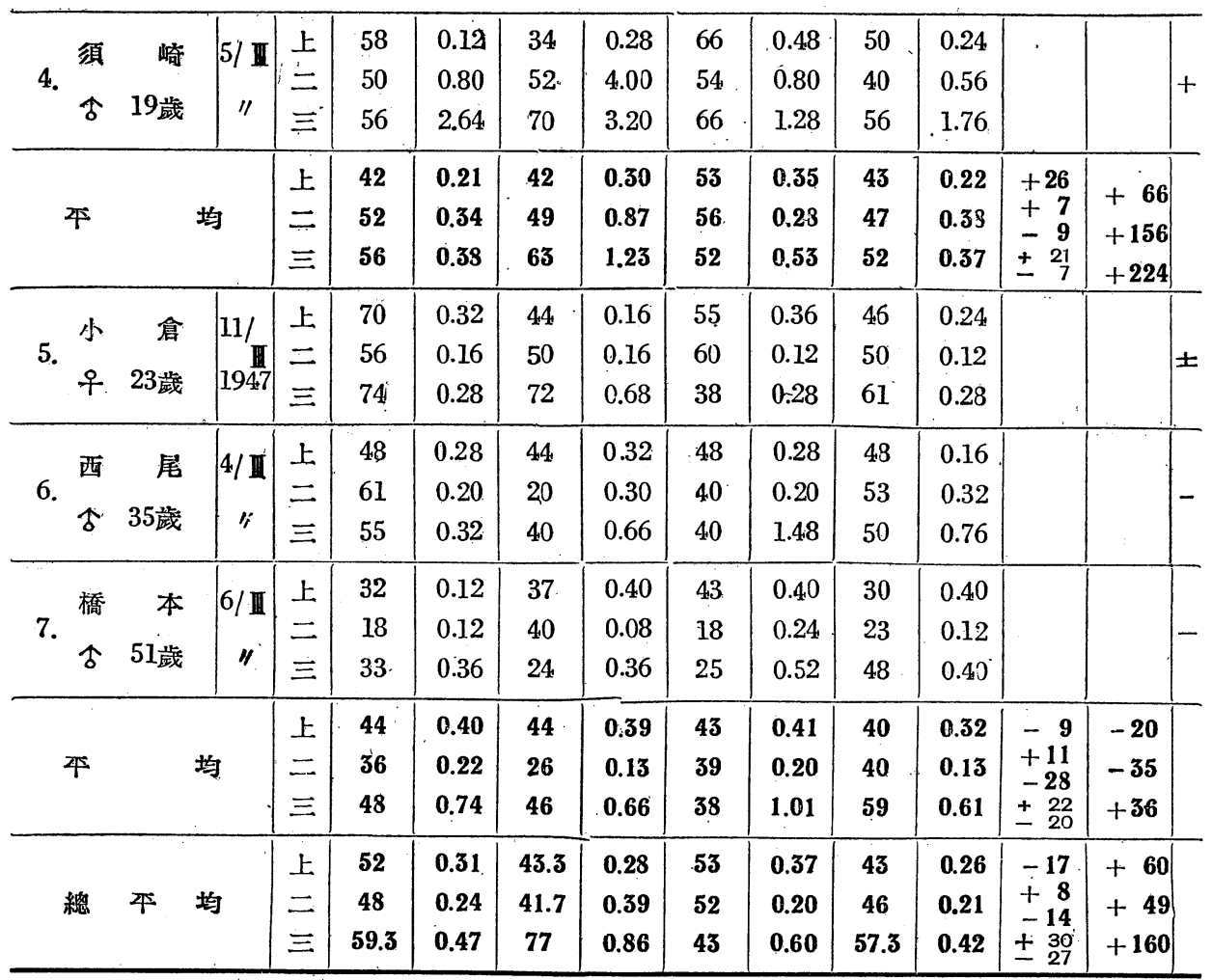

$$
\text { 第五表 }
$$

$$
\text { I アドレナリン II ピロカルピン }
$$

III アトષピシ
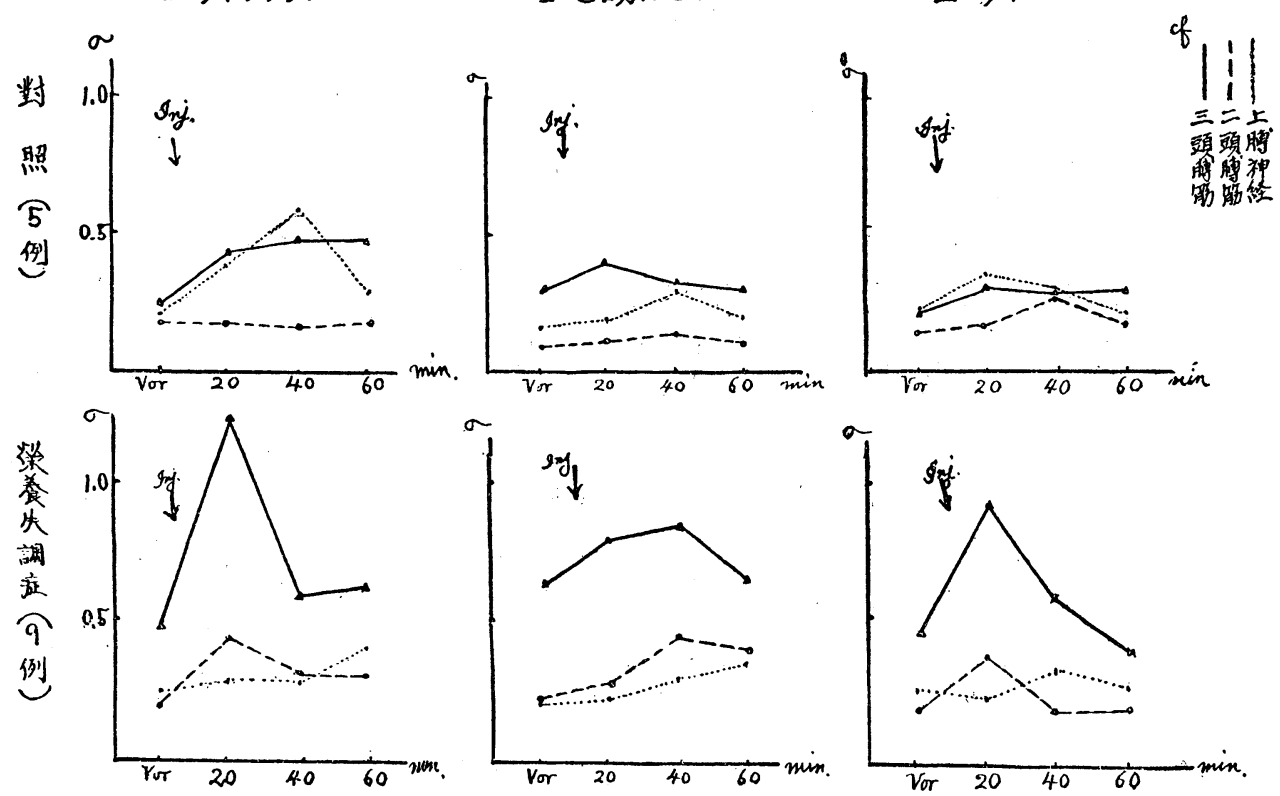

第 25 卷 7 9 
第 6 表 榮養失調症卜對炤卜 自律神經毒=依儿 「くろなきし一」䫶化率ノ比

\begin{tabular}{l|c|c|c}
\hline & あどれなりん & びろかるびん & あとろびん \\
\hline 上膞神經 & 0.37 & 1.03 & 3.53 \\
二頭嘎筋 & 20.00 & 8.00 & 1.20 \\
三頭㯖筋 & 2.00 & 1.38 & 53.33 \\
\hline
\end{tabular}

神經ノ拮抗作用 $\nabla$ 相對的三筧七得ルニ 過ギザルヨ以テ，三薬物共二反應陰性 ナル例八機能正常ナルカ，或八兩神經 共二緊張異常つ狀態ニテ斥㩱シアルモ フナルカ不明ナリ．然ル二張8) びろ かるぴん反應ヨリあとろぴん反鹰ノ方 銃解ナリトノ說ヨリスレバ，本症二於 テ八兩神經共=緊張低下セル

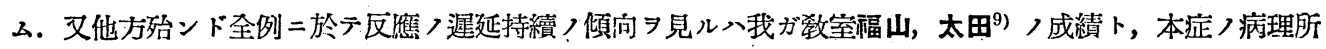

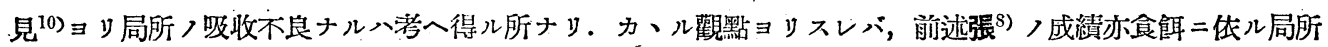
，吸收障害二影響セラル、ヨ否定シ得ザルベシ。次二其ノ際二於ヶル Ch 7 見ル二, 對照=比シ變化率一般 ニ大ナル八, 兩神經共二不安狀態ニアルシ示スモノ/如ク，病變11)著シト思ハルル屈筋ハあどれなりんぴ ろかるびん二銳敏ニシテ, 病變少キ神經, 保筋ガあとろびん二銳敏ナル八藥效學的機能檢查成漬ト一致シ, 且ッ筋刺戱性〉衰弱 $コ$ 示スモノト思惟セラル。

\section{結 論}

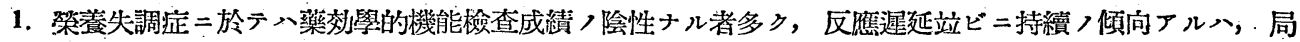

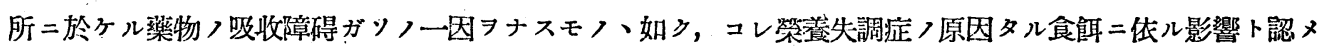
ラル.

2.くろなきしーニ現ハレタル變化率ノ過大八, 自律神經ノ過敏ト言ハンョリハムシロ終未器關, 即于筋

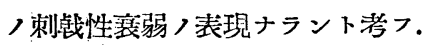

3. 本泟二於ヶル自律科經系八, 緊張低下ヨyモ寧口不安ノ狀態ニアルモノト思惟ス.

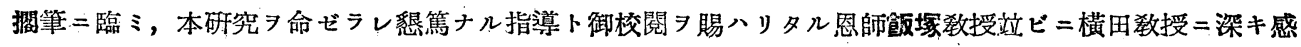
謝ノ意 ヨ表ス.

本研究ハ女部省科學獎勵資金ニ貝フ所少カラズ訅シテ謝意习表ス。

\section{文献}

1）佐々貫之：日米醫學. 1卷5〜 6號，135頁（昭 $21 ， 12$ ).

2）堂野前維摩鄉：同誌. 146頁, 同.

3) 吳健 : 自律神經系. (昭10).

4) 上田春治郎：日新醫學. 12年6號，1027頁 (大正 12 ).

5）沖中重雄：沿療. 28兊1 2 號，9頁. (昭21，2).

6) Weisz, S.: Deut. Z. f. N. h. 121 S.1 \&S.34 (1931).

7) Dresel : Deut. Med. Wochenschr. Nr.35 s.955 (1919).

8) 張交鉁: 兒科雜誌. 48㓬1號, 24頁, 35頁, (昭 18 ).

9）福山健二，太田正：日本內分泌學會雜誌. 22卷1 6號，11頁，(昭 $21 ， 6$ ).

10）瀧澤延次郎：日米醫學. 1卷5～6號，151頁，(昭 $21 ， 12$ ).

11）直，松永，椎野：日本內分泌學會雜誌二發表，豫定. 